\title{
Adenocarcinoma of the nose and paranasal sinuses in shoemakers and woodworkers in the province of Florence, Italy (1963-77)
}

\author{
F CECCHI, ${ }^{1}$ E BUIATTI, ${ }^{1}$ D KRIEBEL, ${ }^{2}$ L NASTASI, $^{1}$ AND M SANTUCCI ${ }^{3}$
}

From the Centro per le Malattie Sociali della Provincia di Firenze, ${ }^{1}$ Italy, the Center for the Biology of Natural Systems, ${ }^{2}$ Washington University, St Louis, Missouri, USA, and Istituto di Anatomia e Istologia Patologica, ${ }^{3}$ Università di Firenze, Italy

ABSTRACT Adenocarcinoma of the nose and paranasal sinuses has been associated with occupational exposure to wood and leather dust. Strong evidence has been found for such an association in Florence, Italy, from 1963 to 1977 . Sixty-nine cases of primary cancer of the nose and paranasal sinuses were identified from hospital records. There were 13 cases of adenocarcinoma, 11 of which were successfully traced and interviewed (patient or relative). Of the 11 cases, three were woodworkers with substantial exposure to wood dust (17 years' average employment) and seven were shoemakers, mostly trimmers. When matched to either of two separate sets of controls (non-cancer hospital patients, and non-adenocarcinoma nose or paranasal sinus cancer patients), the association with occupation was statistically significant. Smoking was ruled out as a source of bias.

Cancer of the nose and paranasal sinuses is rare in the general population. In the past decade reports from England, ${ }^{1-7}$ France, ${ }^{8-13}$ the United States, ${ }^{14-17}$ Denmark, ${ }^{18}$ and Australia ${ }^{19}$ have shown an association between these cancers, particularly adenocarcinoma of the nose and paranasal sinuses, and exposure to wood dust. Both Acheson ${ }^{6}$ and Hadfield ${ }^{3}$ have reported a significantly high incidence of adenocarcinoma of the nasal cavity and paranasal sinuses among workers in the furniture and shoe industries in England exposed to wood or leather dust, or both. We present evidence for an association between leather and woodworking and mortality from adenocarcinoma of the nose and paranasal sinuses in Florence.

The province of Florence (population 1150000 in 1971) has a diverse economy with little heavy industry. Almost 1\%(10 174 in 1971) of the population is engaged in shoe manufacturing, an industry entirely separate from the handbag manufacturing industry. Much of the shoe manufacturing is done in small establishments and home work shops. As the home work is often not reported to the government the census certainly underestimates the size of

Requests for reprints to: Dr E Buiatti, Centro per le Malattie Sociali, Viale Volta 171, Firenze, Italia

Received 13 July 1979

Accepted 20 February 1980 the work force. Between 1961 and 1971 the size of the reported work force in the shoe industry increased by $25 \%$. A previous paper identified polyneuropathies among these leather workers from heavy solvent exposure in poorly ventilated workshops. ${ }^{20}$

\section{Materials and methods}

As no cancer registry yet covers the province of Florence, records of the otorhinolaryngology clinic and the Radiology Institute of the University of Florence for 1963-77 were searched, and 69 patients (47 male, 22 female) with primary cancer of the nasal cavity and paranasal sinuses identified.

Three of the 69 were excluded because biopsy results were missing. For each of the remaining 66 an interview was attempted with the patient or a relative if the patient had died. The interview was conducted by a specially trained social worker, and data on occupational history, smoking habits, and other relevant issues were collected. Four patients (including two with adenocarcinoma) could not be located.

To determine the accuracy of the type of tumour given in the hospital record, $47(76 \%)$ of the 62 cases with complete biopsy and interview data were reviewed by an independent pathologist, and classified by type of tumour. 
A control group for the cases of adenocarcinoma was constructed from patients without malignant disease admitted to the department of internal medicine in the University Hospital. Controls were matched to patients by sex, age ( \pm 5 years), place of residence (strongly associated with socioeconomic status), smoking habits, and year of hospital admission ( \pm 5 years). The controls received the same interview as the cases.

A standard chi-square analysis was used to compare cases to controls.

\section{Results}

Table 1 summarises the 66 cases for whom biopsy data were available. Sex and median age by histological type are also shown. The results of an independent review of histological type are shown in table 2. Overall, $85 \%$ of the classifications listed in the hospital records were correct according to the independent review. For adenocarcinoma $89 \%(7 / 8)$ of the original classifications were confirmed. One case of adenocarcinoma was reclassified as mucoepidermoid tumour, but one epidermoid carcinoma was termed adenocarcinoma after review, so the overall number was unchanged. Because not all the cases could be reviewed for histological type, and because the results of this review of a large sample indicated overall accuracy in histological classification, the type listed in the hospital record was used in this study.

A preliminary analysis indicated that leather and wood work were often reported by the patients with adenocarcinomas, so these were matched to controls as has already been described. Table 3 summarises the relevant data for the 13 patients with adenocarcinoma (two could not be located for interview), and table 4 gives the distribution of patients with

Table 1 Histological type, sex, and median age of all 66 patients with biopsy performed

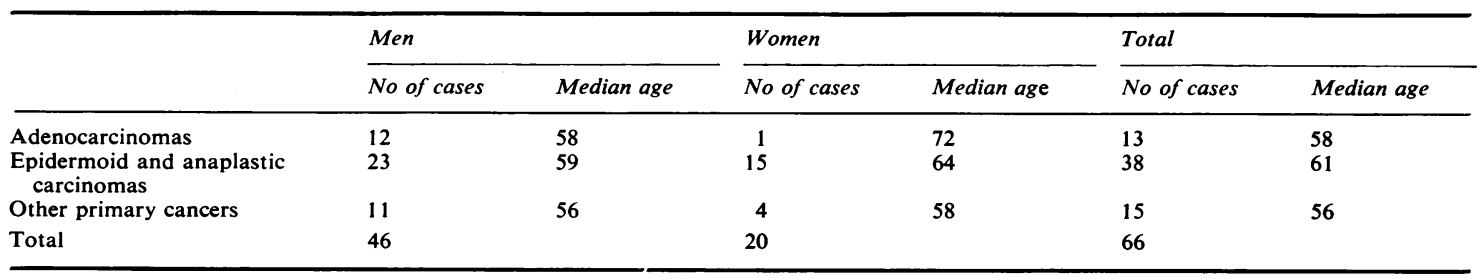

Table 2 Comparison of histological classifications by original diagnosis and by an independent pathologist for 47 patients

\begin{tabular}{llcrl}
\hline $\begin{array}{l}\text { Histological type in } \\
\text { original diagnosis }\end{array}$ & \multicolumn{4}{l}{ Histological type established by independent review } \\
\cline { 2 - 5 } & Adenocarcinomas & Epidermoid carcinomas & Anaplastic carcinomas & Other primary cancers \\
\hline Adenocarcinomas & 7 & 0 & 0 & 1 \\
Epidermoid carcinomas & 1 & 16 & 0 & 1 \\
Anaplastic carcinomas & 0 & 4 & 4 & 0 \\
Other primary cancers & 0 & 0 & 0 & 13 \\
Total & 8 & 20 & 4 & 13 \\
\hline
\end{tabular}

Table 3 Relevant data on patients with adenocarcinoma

\begin{tabular}{|c|c|c|c|c|c|}
\hline Case No & $\operatorname{Sex}$ & Age at diagnosis & Occupation & Length of employment (years) & Latent period (years) \\
\hline 1 & $\mathbf{M}$ & 64 & Woodworker & 13 & 31 \\
\hline 2 & $\mathbf{M}$ & 47 & Shoemaker (trimming) & 7 & 32 \\
\hline 4 & $\mathbf{M}$ & 73 & Shoemaker and repairer & 55 & 53 \\
\hline 5 & $\mathbf{M}$ & 61 & Shoemaker* & 20 & 35 \\
\hline 6 & $\mathbf{M}$ & 66 & Shoemaker (trimming) & 40 & 40 \\
\hline 7 & $\mathbf{M}$ & 44 & Woodcutter & $?$ & $?$ \\
\hline 9 & $\mathbf{M}$ & 53 & Shoemaker (trimming) & 30 & 30 \\
\hline 10 & $\mathbf{M}$ & 62 & Woodworkert & 10 & 30 \\
\hline 11 & $\mathbf{M}$ & 44 & Shoemaker (trimming) & 7 & 35 \\
\hline 12 & $\mathbf{M}$ & 63 & ? & $?$ & ? \\
\hline 13 & $\mathbf{F}$ & 72 & $?$ & $?$ & $?$ \\
\hline & & & & & median: 36 \\
\hline
\end{tabular}

* Also exposure to wood dust.

†Also home work as a shoemaker (10 years). 
Table 4 Distribution of patients with adenocarcinoma and controls by occupation

\begin{tabular}{lllll}
\hline & Shoemakers & Woodworkers & Others & Total \\
\hline Adenocarcinomama & 7 & 3 & 1 & 11 \\
Controls & 0 & 2 & 20 & 22 \\
Total & 7 & 5 & 21 & 33 \\
\hline
\end{tabular}

$x^{2}=23 \cdot 31$.

$\mathrm{p}\left(x^{2}\right)=<0.0001$.

adenocarcinoma and controls by occupation. Sixty-four \% (7/11) of the patients with adenocarcinoma had occupational experience as shoemakers, whereas none of the controls followed that occupation. Twenty-seven per cent of cases (3/11) and $9 \%$ of controls $(2 / 22)$ had occupations exposed to wood dust.* These differences were statistically significant $(p<$ 0.001 ) (table 4). When the occupations of patients with adenocarcinoma were compared with those of patients with carcinoma and also other primary cancer of the nose and paranasal sinuses (table 5), the patients with adenocarcinoma were again more often shoemakers and woodworkers than were the other groups, and this difference was also statistically significant $(p<0.001)$. Among these patients without malignant disease no occupational associations were observed. In the analysis of patients with adenocarcinoma only men aged 45-75 were included, because nearly all (9/11 with occupation known) the patients with adenocarcinoma are clustered in this older cohort.

Table 5 Distribution of patients with adenocarcinoma and other cancer by occupation (men aged 45-75)

\begin{tabular}{lllcc}
\hline & Shoemakers & Woodworkers & Others & Total \\
\hline $\begin{array}{l}\text { Adenocarcinomas } \\
\begin{array}{c}\text { Epidermoid and } \\
\text { anaplastic }\end{array}\end{array}$ & 2 & 3 & 0 & 9 \\
$\begin{array}{c}\text { carcinomas } \\
\begin{array}{c}\text { Other primary } \\
\text { cancers }\end{array}\end{array}$ & 0 & 0 & 17 & 19 \\
\begin{tabular}{l} 
Total \\
\hline$x^{2}=25 \cdot 68$.
\end{tabular} & 8 & 3 & 5 & 5 \\
$p\left(x^{2}\right)=<0.0001$. & & 22 & 33 \\
\hline
\end{tabular}

A potentially confounding factor in this study is smoking habit. As shown in table 6, smoking does not appear to be associated differentially with cancer of any histological type studied. $†$ Further-

\footnotetext{
*The case listed as "wood cutter" cut wood with an axe, and the interview did not identify significant exposure to wood dust. He was not considered to have been exposed to wood dust.
}

†Again the analysis was restricted to the only sizable cohort, men aged 45 to 75 years at diagnosis.
Table 6 Comparison of smoking habits of patients with adenocarcinoma and patients with cancer of other histological types (men aged 45-75)

\begin{tabular}{lcclr}
\hline & Adenocarcinomas & $\begin{array}{l}\text { Epidermoid and } \\
\text { anaplastic } \\
\text { carcinomas }\end{array}$ & $\begin{array}{l}\text { Other } \\
\text { primary } \\
\text { cancers }\end{array}$ & Total \\
\hline Smokers & 7 & 15 & 4 & 25 \\
Non-smokers & 4 & 4 & 1 & 9 \\
Total & 11 & 19 & 5 & 34 \\
\hline
\end{tabular}

$\chi^{2}=0.95$

$\mathbf{p}\left(x^{2}\right)=0.62$.

more, the chi-square analysis of the data in table 6 was not statistically significant $(p=0.62)$. Smoking habits are thus unlikely to be a source of bias in this population.

\section{Discussion}

Adenocarcinoma of the nasal cavity and paranasal sinuses is a rare cancer in Florence, as elsewhere, with only 13 cases reported in 15 years. Our data show, however, that this cancer occurs predominantly among men $($ male/female ratio $=12)$ heavily exposed to wood or leather dust. Among the seven shoemakers with adenocarcinoma, five worked in industry, mainly in trimming operations. The interviews indicated that they were heavily exposed to leather dust. The two other shoemakers were primarily shoe-repairers. This suggests a direct link between adenocarcinoma and exposure to leather dust.

Of the three woodworkers, one also repaired shoes at home for 10 years and so was exposed to both leather and wood dust. The others had small woodworking shops, and it was not possible to determine the extent of their exposure to wood dust.

The average latent period between the start of exposure and diagnosis of the disease was 36 years (33 for woodworkers, 37 for leather workers). This is a short latent period for this type of cancer, but may be due to the intensity of exposure (probably not less than ten hours a day, six days a week) and the poor ventilation of the work rooms.

A definite carcinogenic agent has not been identified in leather or wood, although chromate salts and tannic acid used in leather tanning are suspected carcinogens. ${ }^{21}$ If they or some other common leather ingredients are responsible for nasal adenocarcinoma, then a large population is still at risk of this disease.

\section{References}

1 Acheson ED, Hadfield EH, MacBeth RG. Carcinoma of the nasal cavity and accessory sinuses in woodworkers. Lancet $1967 ; \mathrm{i}: 311-2$. 
${ }^{2}$ Acheson ED, Cowdell RH, Hadfield E. Nasal cancer in woodworkers in the furniture industry. $\mathrm{Br} \mathrm{Med} \mathrm{J}$ 1968 ;ii:587-96.

${ }^{3}$ Hadfield EH. A study of adenocarcinoma of the paranasal sinuses in woodworkers in the furniture industry. Ann $R$ Coll Surg Engl 1970;46:301-19.

${ }^{4}$ Hadfield EH. Cancer hazard from wood dust and in the boot and shoes industry. Ann Occup Hyg 1972;15:39-41.

${ }^{5}$ Acheson ED, Cowdell RH, Rang E. Adenocarcinoma of the nasal cavity and sinuses in England and Wales. Br J Ind Med 1972;29:21-30.

${ }^{6}$ Acheson ED. Nasal cancer in the furniture and boot and shoe manufacturing industries. Prev Med 1976;5:295315.

7 Andersen HC, Andersen I, Solgaard J. Nasal cancers, symptoms, and upper airway function in wood workers. Br J Ind Med 1977;34:201-7.

${ }^{8}$ Gignoux M, Bernard P, Gignoux B. Cancer de l'ethmoide et categories socio-professionelles. $J \mathrm{Fr}$ Otorhinolaryngol $1971 ; 20: 1109-12$.

9 Adenis L, Von Kemmen B, Egret G, Demaille A. Adenocarcinomes de l'ethmoide chez les ouvriers exposés aux poussières de bois. Archives des Maladies Professionelles de Medicine 1973;34:644-6.

${ }^{10}$ Leroux RJ. Les cancers de l'ethmoide chez les travailleurs du bois. Cahiers d'Otorhinolaryngologie 1974;9:585.

${ }^{11}$ Haguenauer JP, Romanet P, Duclos JC, Guinchare R. Les cancers professionelles de l'ethmoide. Archives des Maladies Professionelles de Medicine 1976;37:819-23.

12 Veltin J. Enquete sur les cancers des fosses nasales et des cavites sinusielles dans la region Lorraine. Archives des Maladies Professionelles de Medicine 1977;38:701-6. ${ }^{13}$ Curtes JP, Trotel E, Bourdinin J. Les adenocarcinomes de l'ethmoide chez les travailleurs du bois. Archives des Maladies Professionelles de Medicine 1977;38:773-86.

${ }_{14}$ Milham S. Mortality experience of the AFL-CIO United Brotherhood of Carpenters and Joiners of America, 1969-1970. Washington, DC: US Dept of Health, Education and Welfare, National Institute of Occupational Safety and Health, 1974. (Publication no (NIOSH) 74-129.)

${ }^{15}$ Brinton LA, Blot WJ, Stone BJ, Fraumeni JF. A death certificate analysis of nasal cancer among furniture workers in North Carolina. Cancer Res 1977;37:3473-4.

${ }^{16}$ Milham S. Neoplasia in the wood and pulp industry. Ann NY Acad Sci 1976;271:294-300.

${ }^{17}$ Brinton LA, Stone BJ, Blot WJ, Fraumeni JF. Nasal cancer in US furniture industry counties. Lancet 1976 ;ii :628.

${ }^{18}$ Mosbech J, Acheson ED. Nasal cancer in furniture makers in Denmark. Dan Med Bull 1971;18:34-5.

${ }^{19}$ Ironside P, Matthews J. Adenocarcinoma of the nose and para nasal sinuses in woodworkers in the State of Victoria, Australia. Cancer 1975;36:1115-24.

${ }^{20}$ Buiatti E, Cecchini S, Ronchi O, Dolara P, Bulgarelli G. Relationship between clinical and electromyographic findings and exposure to solvents in shoe and leather workers. Br J Ind Med 1978;35:168-73.

${ }^{21}$ International Agency for Research on Cancer. Some inorganic and organometallic compounds. Monographs on the evaluation of carcinogenic risk of chemicals to man. Vol 2. Lyon, France: IARC, 1973.

\section{Vancouver style}

All manuscripts submitted to the $\mathrm{Br} J$ Ind Med should conform to the uniform requirements for manuscripts submitted to biomedical journals (known as the Vancouver style).

The $\mathrm{Br} J$ Ind Med, together with many other international biomedical journals, has agreed to accept articles prepared in accordance with the Vancouver style. The style (described in full in Br Med J, 24 February 1979, p 532) is intended to standardise requirements for authors.

References should be numbered consecutively in the order in which they are first mentioned in the text by Arabic numerals above the line on each occasion the reference is cited (Manson ${ }^{1}$ confirmed other reports ${ }^{2-5} \ldots$ ). In future references to papers submitted to the BrJ Ind Med should include: the names of all authors if there are six or less or, if there are more, the first three followed by et al; the title of journal articles or book chapters; the titles of journals abbreviated according to the style of Index Medicus; and the first and final page numbers of the article or chapter.

Examples of common forms of references are:

${ }^{1}$ International Steering Committee of Medical Editors. Uniform requirements for manuscripts submitted to biomedical journals. Br Med J 1979;1:532-5.

2 Soter NA, Wasserman SI, Austen KF. Cold urticaria: release into the circulation of histamine and eosinophil chemotactic factor of anaphylaxis during cold challenge. $N$ Engl J Med 1976;294:687-90.

${ }^{3}$ Weinstein L, Swartz MN. Pathogenic properties of invading micro-organisms. In: Sodeman WA Jr, Sodeman WA, eds. Pathologic physiology: mechanisms of disease. Philadelphia: W B Saunders, 1974:457-72. 